\title{
EARLY DEVONIAN TRILOBITES FROM THE SIERRA DE LAS MINITAS, NORTHERNMOST PRECORDILLERA (LA RIOJA PROVINCE), ARGENTINA
}

\author{
JUAN J. RUSTÁN ${ }^{1}$, N. EMILIO VACCARI ${ }^{1}$ AND RICARDO A. ASTINI ${ }^{2}$
}

${ }^{1}$ Centro de Investigaciones en Ciencias de la Tierra (Consejo Nacional de Investigaciones Científicas y Técnicas-Universidad Nacional de Córdoba) - Centro de Investigaciones Paleobiológicas (Universidad Nacional de Córdoba) - Universidad Nacional de La Rioja. Av. Vélez Sársfield 299, X5000JJC Córdoba, Argentina. jjrustan@conicet.gov.ar; evaccari@efn.uncor.edu

${ }^{2}$ Centro de Investigaciones en Ciencias de la Tierra (Consejo Nacional de Investigaciones Científicas y Técnicas - Universidad Nacional de Córdoba) - Centro de Análisis de Cuencas-Cátedra de Estratigrafía y Geología Histórica (Universidad Nacional de Córdoba). Av. Vélez Sársfield 1611, 2 Piso, oficina 7, X5016GCA Córdoba, Argentina.raastini@com.uncor.edu

Abstract. Early Devonian trilobites are described based on material from Sierra de Las Minitas, in the northern extent of the Precordillera, western Argentina. This diverse fauna, the first one known from La Rioja Province, includes a species of the phacopid Paciphacops (Paciphacops) Maksimova, the calmoniids Talacastops zarelae Edgecombe, Vaccari and Waisfeld and Tormesiscus Waisfeld, Edgecombe and Vaccari, together with a proetid (Unguliproetus? sp.) and a dalmanitid. Fossils are preserved in nodules within a strongly folded dark and bioturbated shaley succession, included in a structural and stratigraphically complex geological setting. The taxonomic composition and taphonomic signature of the studied fossil locality are closely similar to those recognized within the lower part of the Talacasto Formation at Las Aguaditas section in San Juan Province. Lithologic and faunistic similarities allow a reliable stratigraphic correlation between both localities; therefore, the trilobite bearing rocks from the Sierra de Las Minitas are interpreted as the northernmost outcrops of the Talacasto Formation in the Argentine Precordillera and are considered to be Lochkovian in age. The remarkable lateral continuity of this fossiliferous stratigraphic interval indicates, as previously suggested, the development of a wide muddy-shelf setting in the Early Devonian Precordillera Basin.

Key words. Trilobites. Devonian. Talacasto. Precordillera. La Rioja. Argentina.

Resumen. TRILOBITES DEL DEVÓNICO TEMPRANO DE LA SIERRA DE LAS MINITAS, PRECORDILLERA MÁS SEPTENTRIONAL (PROVINCIA DE LA RIOJA), ARGENTINA. Se describe una asociación particular de trilobites del Devónico Inferior de la Sierra de las Minitas, Precordillera de la Provincia de La Rioja, Argentina. Esta fauna, la primera conocida para el Devónico de La Rioja, es diversa y se integra por una especie del facópido Paciphacops (Paciphacops) Maksimova, los calmónidos Talacastops zarelae Edgecombe, Vaccari and Waisfeld y Tormesiscus Waisfeld, Edgecombe and Vaccari, junto con un proétido (Unguliproetus? sp.) y un dalmanítido. Los fósiles se encuentran preservados en nódulos bioturbados dentro de una sucesión de pelitas oscuras fuertemente plegada y fallada, incluida en un contexto geológico estructural y estratigráficamente complejo. La composición taxonómica y signatura tafonómica de la localidad fosilífera estudiada resulta estrictamente similar respecto de lo reconocido en la parte baja de la Formación Talacasto, en la sección de Las Aguaditas, Precordillera de la Provincia de San Juan. Las similitudes litológicas y faunísticas permiten una correlación confiable entre ambas localidades y, por lo tanto, los niveles portadores de trilobites de la Sierra de las Minitas son interpretados como los afloramientos más septentrionales de la Formación Talacasto en la Precordillera Argentina y considerados de edad lochkoviana. La notable continuidad lateral de este intervalo fosilífero está de acuerdo con la interpretación de un ambiente depositacional de plataforma fangosa, previamente propuesto para la cuenca de Precordillera durante el Devónico Temprano.

Palabras clave. Trilobites. Devónico. Talacasto. Precordillera. La Rioja. Argentina.

Devonian trilobite faunas from Argentina have been reported from a number of localities along the proto-Andean basins of South America. However, work in recent years has allowed refinement and separation of Silurian and Devonian horizons among several of these localities previously considered Devonian.

True Silurian records include those from Cerro Rincón in the western Puna of Salta Province (Aceñolaza et al., 1972a; Aceńolaza et al., 1972b; Baldis et al., 1973; Isaacson et al., 1976; Baldis and Longobucco, 1977b; Baldis and González, 1981a; Benedetto and Sánchez, 1990; Rubinstein and Vaccari, 2004); Sierra de Santa Bárbara and Sierra de Zapla of Jujuy Province to the north (Baldis, 1972; Baldis et al., 1976; Baldis and González, 1981a; Grahn and Gutiérrez, 2001; Rickards et al., 2002); Cerro del Fuerte in the Precordillera of San Juan Province to the west (on Andinacaste, Benedetto et al., 1992a; Edgecombe et al., 1994b); and some data from Sierra Grande of Río Negro Province in northeastern Patagonia (Benedetto et al., 1992b). In turn, reliable Devonian trilobite records involve data from the 
subsurface of the Chaco plain in Santiago del Estero Province (Mingramm and Russo, 1972; Baldis and González, 1981b; Antonelli and Ottone, 2006), fragmentary remains from the Sierras Australes (Sierra de La Ventana) of Buenos Aires Province (Keidel, 1916), also from Sierra Grande in Río Negro Province (Cuerda and Baldis, 1971), as well as the better known faunas from Malvinas Islands (Richter and Richter, 1942; Edgecombe, 1994; Pires de Carvalho, 2006).

Yet, the bulk of well-known Devonian trilobites from Argentina derive from the Precordillera Basin in San Juan Province. Within the Precordillera fold and thrust belt, the far west (Western Precordillera) has provided Middle to Late Devonian trilobites (Amenábar, 2009, Baldis, 1967; Furque and Baldis, 1973; Baldis and Sarudiansky, 1975; Baldis and Longobucco, 1977a; Baldis, 1979), whereas Early Devonian trilobites, although more abundant, are only known from the Central Precordillera to the east, almost exclusively from the widespread Talacasto Formation.

Effectively, since the pioneering works of Thomas (1905),
Stappenbeck (1910) and Keidel (1921), contributions to the understanding of the Talacasto Formation trilobites (although still mainly descriptive) were made by Castellaro (1966), Harrington (1967), Padula et al. (1967), Cuerda and Baldis (1971), Baldis (1967; 1975a, b, 1979), Baldis and Peralta (1991), Waisfeld et al. (1994), Rustán (2008), and Holloway and Pires de Carvalho (2009). Otherwise, further contributions such as those of Edgecombe et al. (1994a) and Vaccari et al. (1994) have focused on systematic and phylogenetic aspects of these faunas, mainly the calmoniids.

Outside the Talacasto Formation, Early Devonian (probably Late Emsian) trilobites of the Precordillera are only known from isolated sclerites from the overlying Punta Negra Formation (Herrera and Bustos, 2001).

A new Early Devonian trilobite assemblage from La Rioja Province is recognized and analyzed herein. These trilobites come from the northernmost extent of the Precordillera and their presence was originally reported by Coughlin (2000) and Vaccari et al. (2008). Systematic aspects and the age of

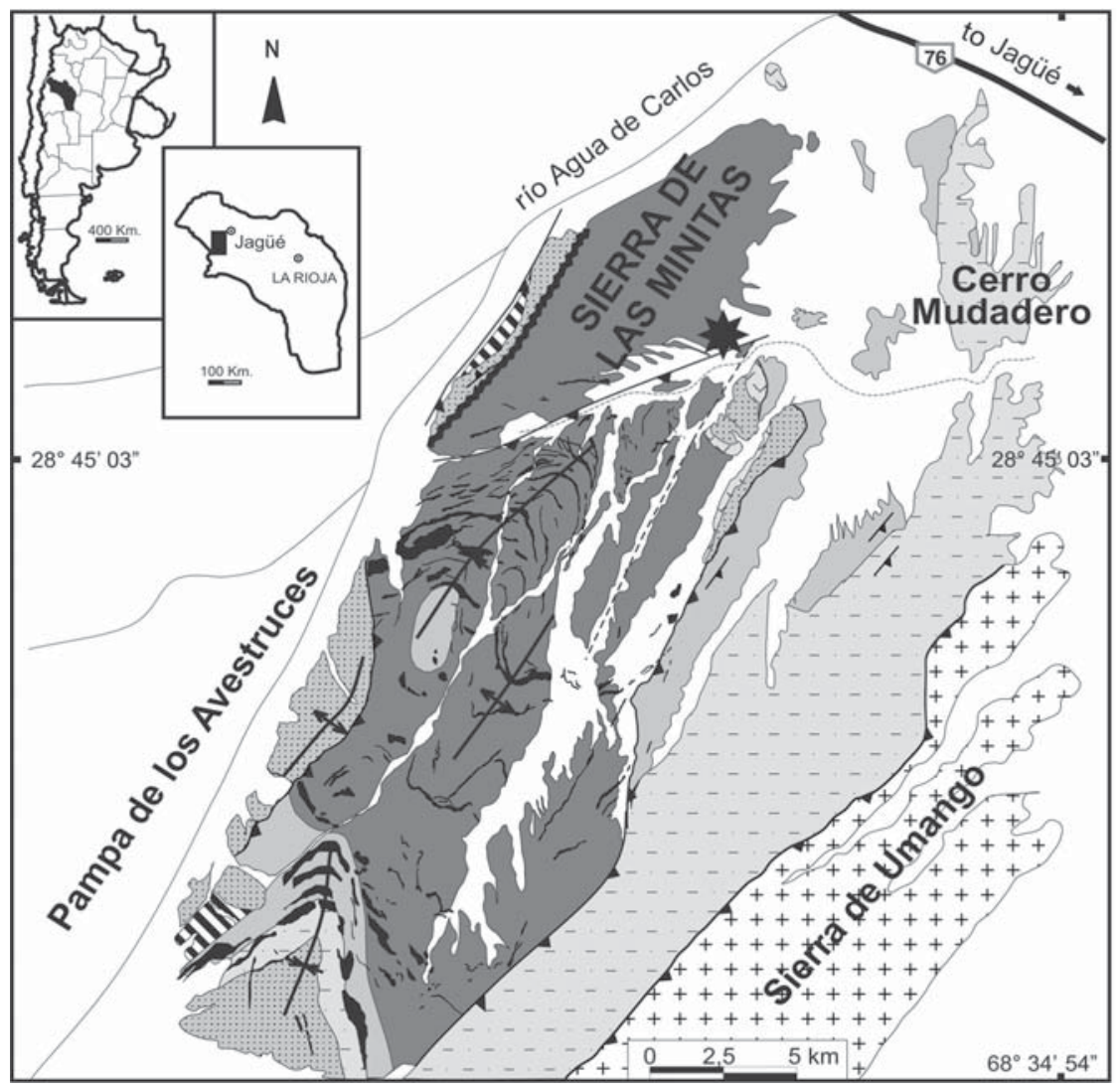

\section{Stratigraphic references}

Upper Paleozoic

N Mulas Muertas Fm

Río del Peñón Fm

Punta del Agua Fm

Cerro Tres Cóndores Fm

Agua de Lucho Fm

LOWER PaleozoIC

Devonian- Mississippian dykes

$\square$ Devonian (partially Lower

Devonian Talacasto Formation)

Mesoproterozoic

++ Umango Basement

Fault with dip indicated
Fault with lower block indicated

Figure 1. Location map and geological information of the studied area: Las Minitas Range Northern Precordillera, northwest of La Rioja Province, Argentina (modified from Coughlin, 2000)/ Mapa de ubicación e información geológica del área estudiada: Sierra de las Minitas, Precordillera septentrional, noroeste de la Provincia de La Rioja, Argentina (modificado de Coughlin, 2000). 
this fauna are discussed, together with its implications for correlation and understanding of the Precordillera Basin during the Early Devonian.

\section{GEOLOGICAL SETTING}

The rocks studied are exposed at Sierra de Las Minitas, a set of low mountain ranges located to the west of Bolsón de Jagüé, in northwestern La Rioja Province, Argentina. This region has been considered as the northern continuation of the Sierra de La Punilla in San Juan Province (Caminos et al., 1993), and thus the northernmost reaches of the Precordillera. The area was originally mapped by Aceñolaza (1971) and Caminos et al. (1993), and more recently in detail by Coughlin (2000).

The study area is located nearly $30 \mathrm{~km}$ southwest from the small town of Jagüé, being the last set of ranges immediately to the west of the Sierra de Umango. The Pampa de las Avestruces separates these outcrops from those in the Cordillera Frontal to the west, and the Agua de Carlos and the La Troya rivers bound it to the north and south, respectively (Fig. 1).

The structure of the area is complex and the folded bedding was faulted and intruded by igneous bodies. At least one important folding episode took place prior to the Early Pennsylvanian (Río del Peñón Formation) which overlies it on angular unconformity (this unconformity outcrops to the northeast, see Fig. 1).

Most of the exposures in this area have been previously assigned to the Jagüel Formation (González and Bossi, 1986), a poorly known unit including Devonian and Lower Carboniferous sedimentary rocks (Fauqué and Limarino, 1991; Azcuy and Carrizo, 1995; Carrizo and Azcuy, 1995; Limarino et al., 2006). Coughlin (2000) mapped the area in more detail and recognized a broad set of units that may, in part, fill in the regional gap separating Devonian from Carboniferous rocks elsewhere in the Precordillera (Astini, 1996). Coughlin (2000) described —within the Sierra de Las Minitas-a separate unit that he informally named the Quebrada del Escarabajo Formation. On the basis of a few trilobite remains and $\mathrm{K}-\mathrm{Ar}$ ages in the cross-cutting igneous rocks, he suggested a bulk Devonian age for his new unit. However, between the Devonian trilobite-bearing interval and the unquestionably Carboniferous rocks of the Río del Peńón Formation, several different stratigraphic relationships occur in Sierra de Las Minitas, allowing for a complex history of uplift, erosion and onlapping for the region.

Within the core of the range, glacial diamictites conform- ably cover the studied unit (Astini and Ezpeleta, 2008; Ezpeleta and Astini, 2009). Paleontological (Vaccari et al., 2008) and geochronological data (Coughlin, 2000) -different from the Pennsylvanian Río del Peńón glacial record- seem to point to a Devonian age for this glaciomarine sequence.

The Quebrada del Escarabajo Formation of Coughlin (2000) can be divided into three distinct facies associations: (1) fine-grained green to dark gray bioturbated shales, (2) thoroughly bioturbated sandy siltstones, and (3) rhythmically graded sheet-like sandstones (medium to coarse-grained) and interbedded shales. Toward the top of the unit, the latter association is only present immediately below the unconformity and yields abundant flute casts, indicating depositional processes related to highly concentrated sandy gravity flows (turbidity currents). Dominant paleocurrents suggest a source from the east. No unequivocal wave reworking has been observed in this association. The shale-rich association locally yields carbonate-rich nodules with a variety of fossil remains, among which the Early Devonian trilobites studied herein are the more distinctive forms. Silty facies seem to be transitional between the lower shaly and the upper sandy facies associations. This association includes frequent thin beds of fine-grained sandstones with lenticular and wavy bedding.

\section{MATERIALS AND METHODS}

All materials come from a single collecting site (Dv1, Fig.1). This single productive locality is restricted to a small area around $28^{\circ} 42^{\prime} 50^{\prime} \mathrm{S} / 68^{\circ} 39^{\prime} 29^{\prime \prime} \mathrm{W}$, represented by an interval of a few meters with abundant nodules within greenish-dark grey shaly beds. Partly deformed trilobites are preserved inside dark grey to black carbonate-rich bioturbated nodules commonly covered by a thin layer of iron oxide. The associated faunas from these beds include corals, sponges, bivalves, nautiloids, conulariids and brachiopods, all almost exclusively derived from nodules and thus indicating a preservational bias.

Materials were collected following the same fossil-bearing stratigraphic level and referring to a geologic map, using GPS coordinates. Stratigraphic columns could not be detailed because of the small fossil outcrop and the structurally complex geological setting. Specimens were prepared using needles, pneumatic vibrators, acid, and latex moulds or plasticine squeezes of counterparts. Photographs of specimens -coated with ammonium chloride sublimate and previously stained black- were obtained using a Canon Power Shot S50 digital camera mounted on a Leica MZ75 binocular.

Specimens illustrated herein are housed in the paleon- 
tological repository of the Museo de Ciencias Naturales at the Universidad Nacional de la Rioja, La Rioja, Argentina, numbered with the prefix PULR.

Technical terms, as usually used in trilobite descriptions, are abbreviated as follows: sagittal/sagittally (sag.), exsagittal/ exsagittally (exsag.), transversal/transversely (tr.). Open nomenclature follows criteria by Bengtson (1988).

Institutional abbreviation. PULR, Museo de Ciencias Naturales at the Universidad Nacional de la Rioja, La Rioja, Argentina.

\section{SYSTEMATIC PALEONTOLOGY}

Order Phacopida Salter, 1864

Suborder Phacopina Struve, 1959

Family Phacopidae Hawle and Corda, 1847

Subfamily Phacopinae Hawle and Corda, 1847

Genus Paciphacops Maksimova, 1972

Type species. Phacops logani Hall, 1861, from the Lochkovian of the New Scotland Formation, New York, U.S.A; original designation.

Subgenus Paciphacops Maksimova, 1972

Paciphacops (Paciphacops) sp.

Figure 2.1-9

Material. An almost complete specimen (PULR-118 A-C), two cephala (PULR-121-PULR-124), one cephalothorax (PULR-119 A-J), two thoraces (PULR-123, PULR-125), two thoracopygidia (PULR-122 A-B, PULR-120), one pygidium (PULR-126 A-B).

Description. Known maximum length of exoskeleton (cephalon plus thorax of specimen PULR-118 A) about $38 \mathrm{~mm}$ (Fig. 2.6). Cephalon length about 0.5 of width (sag.); outline in dorsal view with greatest curvature forward medially and laterally in front of anterior end of eye (Fig. 2.4). Anterior margin slightly arched upward in frontal view (Fig. 2.3). Glabella contour sub-rhombic to sub-oval (tr.) (with weakly convex antero- and posterolateral sides and sub-rounded lateral corners between them), with frontal lobe markedly inflated and directed upward, projecting forward and upward beyond the preglabellar furrow in lateral view, comprising about 0.5 of maximum cephalic width; width across frontal lobe about twice the width at occipital ring and approximately equal to sagittal length, with medium-sized sparse tubercles and small densely disposed granules between them (Fig. 2.1-5). Axial furrow gently converging forward from lateral sides of occipital ring to front of $\mathrm{L} 1$ at junction with $S 1$, then strongly diverging anterolaterally at about $75^{\circ}$ from $\mathrm{S} 1$ to widest part of glabellar frontal lobe. Occipital furrow (SO) medially shallow and exceedingly long (sag.). S1 bent forward, weakened medially, becoming apodemal laterally, long (exsag.), rapidly shallowing laterally at junction with axial furrow. S2 faded in general, narrow (exsag.), becoming a shallow incision, sinuous (concave forward medially, then concave backward distally), running approximately transverse. Median branch of S3 of similar depth as S2, yet effaced medially and distally near axial furrow, without observable lateral branch in the available material. LO (occipital ring) long (sag., exsag), medially high, taller than L1, bearing a large dorsal spine and with small lateral lobe. L1 (preoccipital lobe or intercalating ring) moderately long (sag.), low, adpressed to the base of glabella; with small, rounded lateral lobe, as tall as lateral lobe of axial ring, but laterally less extended. L2 subtly defined, transversely elongated. L3 subtly defined, laterally elongated, slightly convex forward. Preglabellar furrow only morphologic structure between ventralmost side of glabellar frontal lobe and dorsal rim of vincular furrow. Preglabellar furrow an anterior continuation of lateral furrow, distinct across entire frontal width (tr.) of glabella, evenly and strongly convex upward in frontal view. Posterior border furrow very long (exsag.) and deep, slightly longer (exsag.) distally, shallowest at junction with axial furrow, postero-laterally directed, deflecting backward beyond fulcrum to genal angle, becoming slightly shallower and continuing as lateral border furrow. Posterior border a strong ridge, running posterolaterally somewhat deflected backward, apparently with dorsolateral spine at fulcrum. Palpebral lobe narrow (tr.), oblong (exsag.) to semi-lunar in outline, with large tubercles arranged nearly in a row, most externally. Palpebral furrow apparently broad (tr.) moderately shallow, slightly convex laterally, following the inner contour of palpebral lobe. Interocular fixigena coarsely tuberculate, slightly inflated to nearly flat, with wide (tr.) subtriangular shape in dorsal view; postocular area of fixigena continuing laterally behind eye as long (tr.) sideburn-shaped prolongation to posteroventral corner of eye (Fig. 2.1). Medium-sized eye with sub-vertical visual surface with lenses not arranged regularly in rows in its upper-middle part. Specimens PULR-118, 119 and 121 appear to have 11-12 vertical rows (counted in the lower edge of the visual surface), with a general maximum of five (more rarely six) lenses. Librigena field sub-vertical below eye, exceedingly reduced to become broad and concave area merging with lateral border furrow. Lateral border furrow deep and wide (tr.), deepest beneath eye, as continuation of posterior border furrow from the genal angle where it is shallowest, then narrowing (tr.) and shallowing toward fron- 


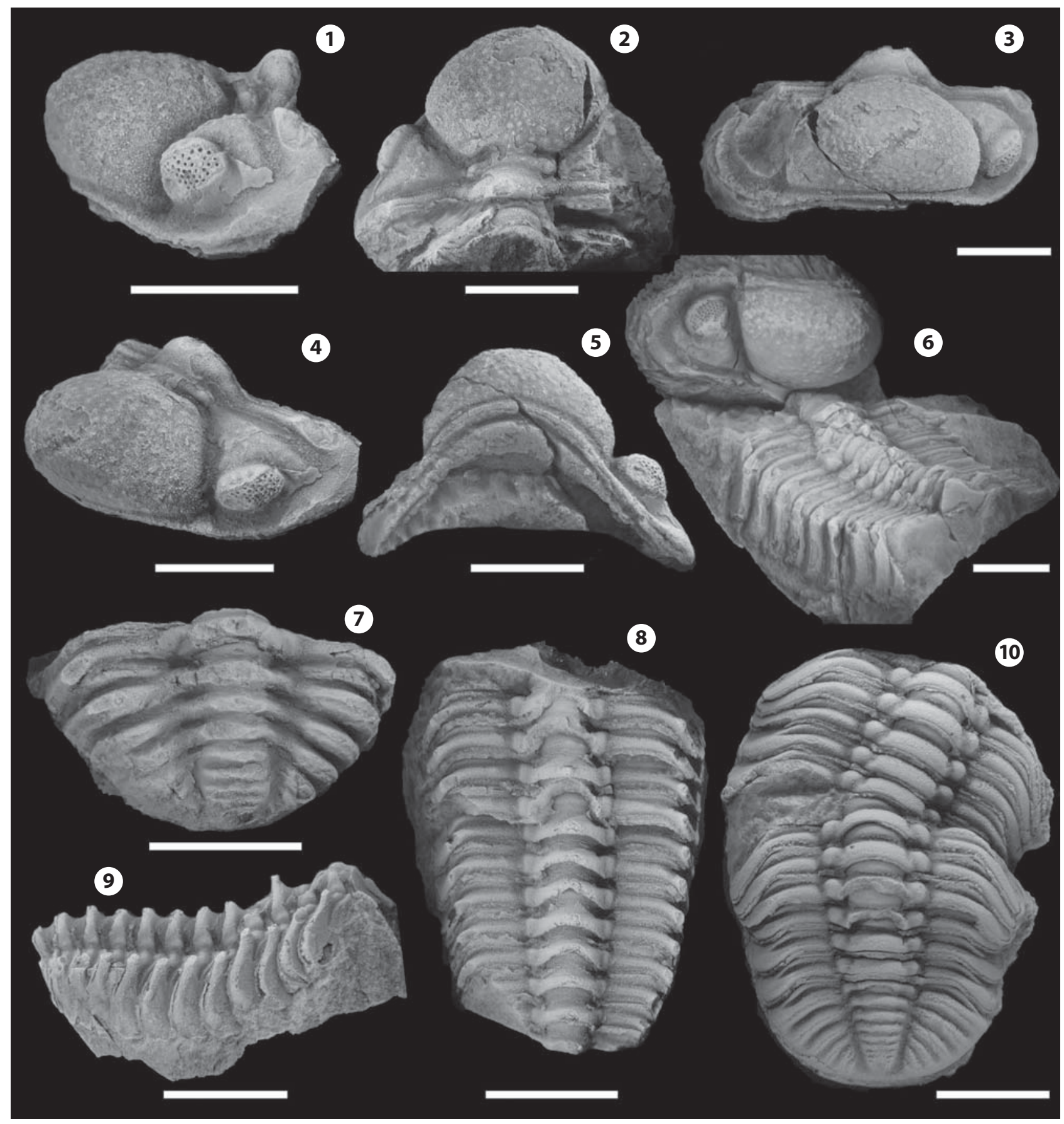

Figure 2. 1-9, Paciphacops (Paciphacops) sp. 1-5, PULR-119 A, cephalon with the first thoracic segment attached; note spines (broken) on axial ring and posterior border at fulcrum / céfalo con el primer segmento toráxico asociado; note las espinas (rotas) en el anillo axial y borde posterior sobre el fulcro; 6, PULR-118 A, posterolateral view of the molt ensemble specimen with the cephalon almost inverted over the thorax/vista posterolateral de una asociación de muda con el céfalo casi invertido sobre el tórax; 7, PULR-126 B, internal mold of a pygidium with the last thoracic segment attached. Note the strong segmentation and ridges on fulcrum instead of clearly developed spines as in the thorax/ molde interno de un pigidio con el último segmento toráxico asociado. Note la fuerte segmentación y aristas sobre el fulcro, en lugar de espinas claramente desarrolladas como en el tórax; 8-9, PULR-120, thorax showing straight (tr.) thoracic segments and pleural furrows, and axial spines on axial ring and pleurae at fulcrum/ tórax mostrando segmentos toráxicos y surcos pleurales rectos (tr.) y espinas sobre los anillos axiales y fulcro; 10, Paciphacops? sp., PULR-127 A, thoracopygidium; note the clearly developed rounded lateral axial lobes on axial rings, absence of axial and fulcral spines, thoracic segments not straight transversely, and not distally subvertically oriented pleurae beyond fulcrum/ toracopigidio; note los lóbulos laterales del anillo axial claramente desarrollados y redondeados, ausencia de espinas axiales y fulcrales, segmentos toráxicos no transversalmente rectos, y pleuras no subverticalmente orientadas distalmente más allá del fulcro. Scale bar/ escala gráfica $=1 \mathrm{~cm}$ 
tal area and continuing as the preglabellar furrow from the junction with the axial furrow, anterolaterally. Lateral border moderately wide (tr.) and inflated, progressively wider (tr.) backward. Posterior border nearly straight, short (exsag.), apparently bearing (material broken, leaving a scar, Fig. 2.1, 4) moderately small and somewhat flattened intergenal spine (Fig. 2.1, 2.3, 2.4, 2.6). Cephalic doublure long (sag.), flattened. Vincular furrow known from poorly preserved material, well developed, evenly arched upward in frontal view, apparently narrowing and shallowing laterally, there becoming crenulated in appearance (Fig. 2.5). Hypostome unknown. Thorax contour elongated sub-oval in dorsal view, with 11 segments (Fig. 2.9). No ornamentation evident on dorsal aspect. Wide (tr.) axial rings (about 0.38 of total segment width in anteriormost segments), very convex dorsally. Medial lobe of axial ring exceedingly short (sag., exsag.), shortest medially, shorter than lateral axial lobe in general, bearing large subcylindrical spine (Fig. 2.8). Articulating half-ring separated from axial ring by moderately deep furrow, but reaching almost same level of axial ring dorsally. Lateral axial lobes incompletely defined, moderately long (exsag.), somewhat laterally elongated, moderately inflated, incompletely set off from the axial medial lobe. Axial furrow exceedingly shallow and moderately wide (tr.), only slightly convex laterally along thorax. Pleurae nearly straight and oriented normally with respect to axis in dorsal view, with sub-horizontal adaxial part much wider (tr.) than abaxial part; the latter abruptly and strongly inclined (almost $90^{\circ}$ ) distally beyond fulcrum. Anterior pleural band ridge-like, much shorter (exsag.) than posterior pleural band, almost transversely oriented. Deep and moderately narrow (exsag.) pleural furrow of angular crosssection, placed anteriorly respect to midpoint (exsag.) of segment at fulcrum, starting as a fine line at junction with axial furrow, running almost transversely in approximately straight manner, widening (exsag.) and deepening distally, reaching a maximum at fulcrum. Large dorsolateral spine at fulcrum (Fig. 2.6, 8-9). Posterior pleural band convex, long (exsag.), flexed backward distally and posterolaterally directed, with deep and short (exsag.) articular furrow running along posterior side, which tapers distally toward fulcrum. Distal part of pleurae subrounded, with flat to barely concave articular facet.

Pygidium medium-sized to proportionally small, wider (approximately double) than long, widely rounded to subtriangular in outline (Fig. 2.7). Axial region convex, segmentation strongly marked. Axial furrows broad (tr.), moderately deep, and approximately straight, with apodemal notches at first two or three anterior rings. Axis about 0.35 of maximum pygidial width anteriorly and 0.80 of pygidial sagittal length, with 7-8 well defined rings plus terminal piece. Short (sag.) axial rings. First 3-4 rings strongly defined, anteriormost two with small insinuated dorsal spine becoming dorsal node on progressively fainter posteriormost rings. Interannular rings long (sag.), clearly separating the rings. Abruptly acuminate posterior tapering without effacement of axial furrows, rendering distinctly delineated posterior the axis. Pleural field with five strong ribs, bearing long (exsag.) and deep pleural furrows, gradually less impressed backwards and more posterolaterally directed. Interpleural furrows well impressed except in last, small pleural ribs. Dorsolateral fulcral spine insinuated at fulcrum of first pleura. Pleural ribs and furrows becoming progressively faint distally, effacing next to pygidial margin, rendering an insinuated pygidial border.

Discussion. Recent phylogenetic analyses by McKellar and Chatterton (2009) brought into question the taxonomic status of Paciphacops and Viaphacops Maksimova, 1972, returning them to subgenera of Paciphacops, as initially proposed by Maksimova (1972). In the same way, other closely allied genera, most interestingly Kainops Ramsköld and Werdelin, 1991, were questioned. We presently follow that proposal, pending a more comprehensive cladistic analysis that includes the majority of species belonging to these discussed taxa, which is necessary in order to review the criteria of their taxonomic recognition.

According to the diagnosis of Maksimova (1972), the recognition herein of Paciphacops (Paciphacops) is based on the preoccipital furrow bent forward and weakened in its middle portion; more or less reduced preoccipital lobe, appressed to the base of the glabella, and cut off behind by straight occipital furrow; lateral angles of glabella drawn out; occipital ring broad (sag., exsag.); and pygidium moderately well segmented with rounded-triangular shape. Moreover, from the characters tested by Ramsköld and Werdelin (1991), the sclera appears to be thickened (character 23) as in $P$. (Paciphacops), which precludes an assignment to $P$. (Viaphacops). Likewise, following Maksimova (1972), the assignment of our material to $P$. (Viaphacops) is ruled out due to the presence of a well distinguished L1, a relatively broad (sag., exsag) occipital ring and a nearly rounded-subtriangular pygidium with strongly expressed segmentation.

Differentiation from Kainops is difficult due to the strong cephalic resemblances between it and Paciphacops, as remarked by McKellar and Chatterton (2009), and a discussion on the validity of Kainops is beyond of the scope of this 
work. In appearance our form could be distinguished from Kainops based on the apparently more thickened sclera, yet the poorly preserved available material does not allow confidence.

Among congenerics previously known from Malvinokaffric basins, the Paciphacops studied here seems related on the basis of cephalic features to P. argentinus (Thomas, 1905) from the Upper Silurian of the Los Espejos Formation, Precordillera of San Juan Province; and P. waisfeldae Edgecombe and Ramsköld, 1994, from the uppermost Silurian-lowermost Devonian of the Catavi Formation from Bolivia. However the presence of spines definitively indicates a different taxon.

This striking feature indicates that the most closely related species of Paciphacops to our taxon is P. (Paciphacops) crawfordae Wright and Haas, 1990, from the late Pragian of the Rosedale Shale, Limekilns district, New South Wales, Australia. Distinctively both forms share intergenal, occipital, axial and fulcral spines which are therefore considered topologically homologous. Other features present in both taxa include similar tuberculation, straight (tr.) pleurae adaxially almost horizontal and distally almost vertical behind the fulcrum, a similar shape of the glabella and glabellar inflation, similar divergence angles of axial furrows in the cephalon, and features of lateral and posterior borders and border furrows.

Both taxa can be reliably considered sister taxa mainly on the basis of spines, an unusual feature among phacopids.

Nevertheless, despite strong similarities, P. (Paciphacops) crawfordae can be differentiated based on the more delicate spines in general, more medially located intergenal spines, better impressed S2 and S1, the former more anteriorly located to delimit a longer (exsag.) L2, and eyes with lenses regularly arranged in 12 vertical rows, rather than in 11 rows as seems to occur in some instances in our material.

All the evidence indicates that the specimens discussed here must represent a new taxon. This will be explored in a forthcoming systematic and phylogenetic specific work, based on more abundant and better preserved material from an identical concretionary level recognized in the lower part of the Talacasto Formation at the Las Aguaditas section, near $10 \mathrm{~km}$ to the Southwest of Jáchal, San Juan Province (for a map see Vaccari et al., 1994). This material is currently under study and will permit a more complete description and a rigorous diagnosis, mainly in eye characters, providing stability in erecting the new species. In accordance with this, the nomenclature is left open for the moment.

As noted by Iwasaki (2006) and other researchers, Paciphacops can be considered cosmopolitan. It is known from eastern and central-western North America, Kazakhstan, Eastern Australia and the Andean region of Bolivia, Perú and Argentina. As this taxon is typical of the Late Silurian-Early Devonian, it has further paleobiogeographic implications for the Malvinokaffric Realm, particularly because it is in agreement with uppermost Silurian-lowermost Devonian dispersals of extra-Malvinokaffric elements. Moreover, such widespread distributions for this period have been recognized for other trilobites in Argentina (Waisfeld et al., 1988; Waisfeld and Sánchez, 1993; Edgecombe et al., 1994b; Edgecombe and Ramsköld, 1994).

\section{Paciphacops? sp. \\ Figure 2.10}

Material. PULR-127A-B, thoracopygidium almost completely articulated, with first five thoracic segments clockwise rotated.

Description. Sub-oval Thorax $3.5 \mathrm{~cm}$ long, with 11 segments. No sculpture other than very subdued granules evenly widespread on dorsal surface. Wide (tr.) axial rings (about 0.38 of total segment width in anteriormost segment, trans-

Figure 3. 1-9, Talacastops zarelae Edgecombe, Vaccari and Waisfeld, 1994; 1-4, PULR-112 A, cephalon showing location and morphology of two types of spines belonging to the anterior sub-marginal row/ céfalo mostrando ubicación y morfología de dos tipos de espinas pertenecientes a la fila anterior submarginal; 5, PULR-113 A, dorsoanterolateral view of a cephalon showing the facial suture and continuation of the raw of spines along posterolateral librigena margin/ vista dorsoanterolateral de un céfalo mostrando la sutura facial y la continuación de la fila de espinas a lo largo del margen posterolateral de la librígena; 6, PULR-116 A, ventral view of a cephalon showing curvature of a row of spines subparallel to the anterior margin, and detail of the anterior doublure developed backward as a platform/ vista ventral de un céfalo mostrando la curvatura de la fila de espinas subparallela al margen anterior, y detalle del doblez anterior desarrollado hacia atrás como una plataform; 7-9, PULR-111 A, pygidium showing granulated sculpture, smooth posterior margin, and blunt spine-like ends of the pleural ribs anterolaterally on the margin/ pigidio mostrando la ornamentación granulada, margen posterior liso, y costillas pleurales a manera de espinas con extremo romo, anterolateralmente sobre el margen; 10-12, Unguliproetus? sp., PULR-128, cephalon showing long (sag.) anterior area, faded glabellar furrows, depressed ogival glabella / céfalo mostrando un área anterior larga (sag.), surcos glabelares tenues, y glabella deprimida de silueta ojival; 13, Dalmanitine, PULR-132, pygidium (latex cast of external mold); note blunt spines on axial rings / pigidio (réplica en látex de mode externo); note las espinas romas en los anillos axiales; 14-15, Tormesiscus cf. hildae Waisfeld, Edgecombe and Vaccari, 1994; 14, PULR-130 B, internal mold of a partially complete articulated specimen/ molde interno de un espécimen articulado parcialmente completo; 15, PULR-129, pygidium (latex replica of external mould); note impressed segmentation and subparallel terrace lines on the doublure/ pigidio (réplica en látex de un molde externo); note la segmentación impresa y líneas en terraza subparalelas en el doblez. Scale bar/ escala gráfica $=1 \mathrm{~cm}$ 

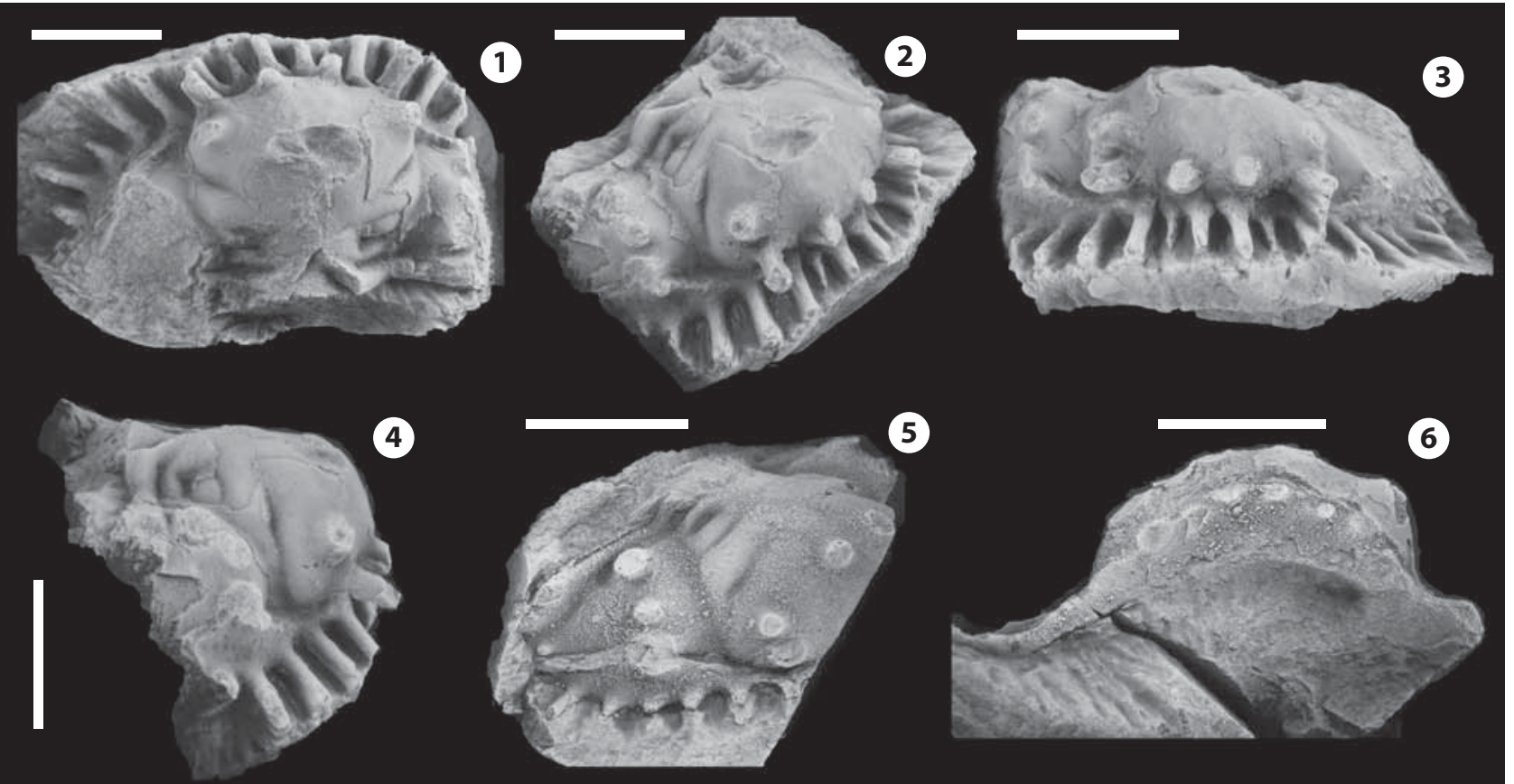

5
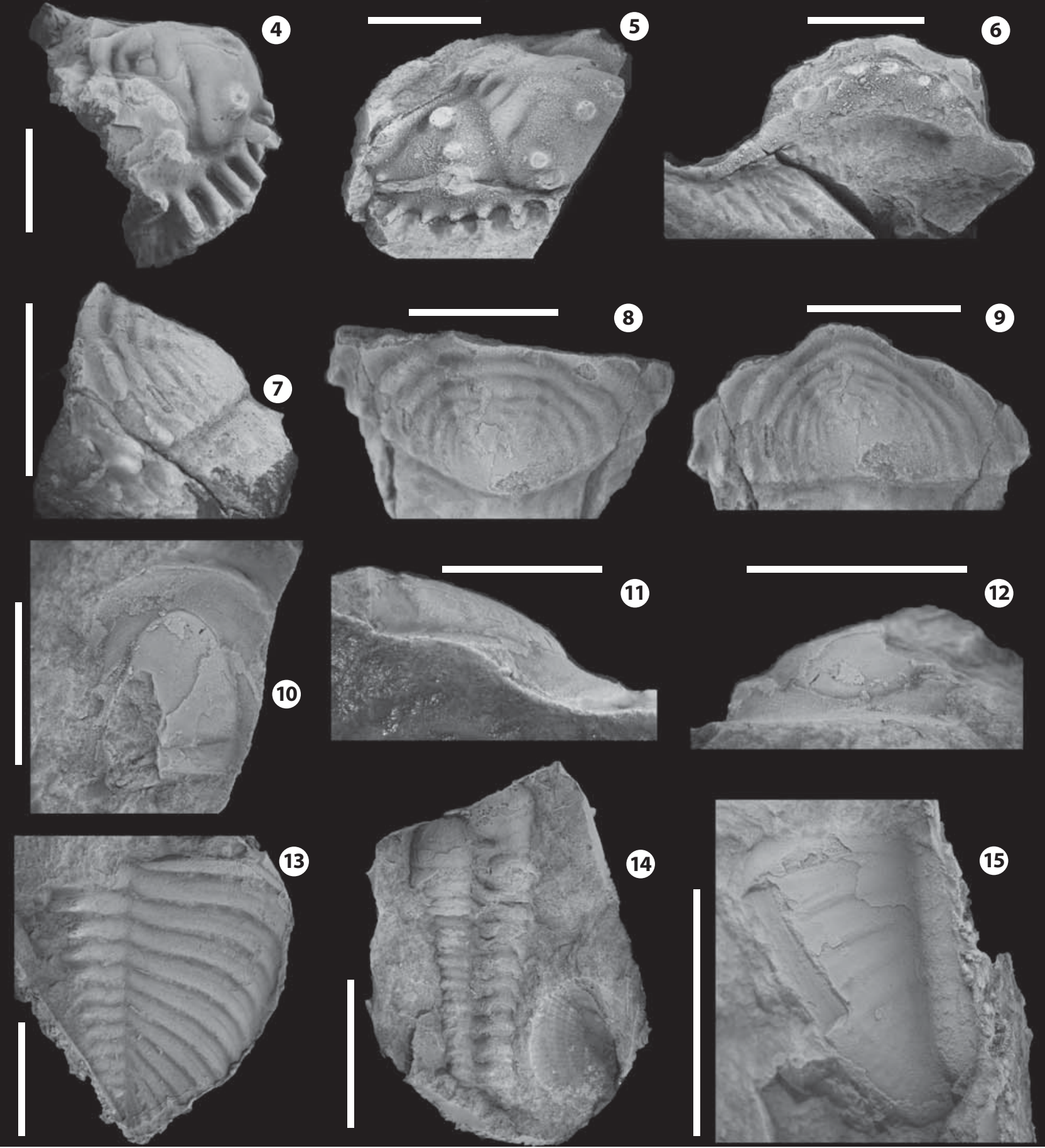
versely), with strong dorsal convexity and very well defined lateral lobes. Medial lobe of axial ring moderately elongated (sag.) and moderately convex. Articulating half-ring separated from axial ring by a deep furrow, but reaching almost the same level as axial ring dorsally. Lateral axial lobes well rounded, bulbous, inflated, set off from medial lobe by a deep anteriormost apodemal pit that continues as a wide (tr.) and somewhat shallow furrow directed posterolaterally. Axial furrow deep and moderately wide (tr.), apparently curving around lateral axial lobes in each segment. Pleurae with both adaxial and abaxial part of similar width (tr.). Deep and wide (exsag.) pleural furrow of angular cross-section, placed anterior to midpoint (exsag.) of segment at fulcrum; shallowing medially, deepest at fulcrum and merging adaxially with axial furrow. It narrows and fades distally, becoming a trace breaching and posterodorsally crossing articulating facet. Anterior pleural band shorter (exsag.) than posterior band, both convex dorsally. Distal part of pleurae subrounded, slightly flattened ventrally. Articulating facet barely concave, evenly covered by very subdued equidimensional granules. Pygidium proportionally large, approximately twice as wide as long sagittally, becoming subtriangular to elliptical in outline. Axial region moderately convex and showing conspicuous segmentation. Axial furrows broad (tr.), moderately deep, approximately straight, posteriorly converging at a $30^{\circ}$ angle. Axis about 0.35 of maximum pygidial width anteriorly and 0.7 of sagittal pygidial length, with eight well defined rings plus terminal piece (although posteriormost two rings somewhat eroded dorsally). Interannular rings only insinuated on posterior part of anteriormost axial rings. Abrupt tapering posterior and effaced axial furrows next to terminal piece rendering closure of axis incomplete posteriorly. Pleural field with six clearly distinguishable ribs, defined by long (exsag.) and deep pleural furrows. Interpleural furrows well impressed except in last, small pleural rib. Pleural ribs and furrows becoming progressively fainter distally, effacing next to pygidial margin, and thus rendering almost smooth pygidial border.

Discussion. Data involving phacopids have been previously known in relation to lithologic units dealt with herein. Baldis and Peralta (1991) reported the genus Reedops Richter and Richter, 1925, in probably late Lochkovian-Pragian levels (from the "middle part") of the Talacasto Formation, at the Río de las Chacritas and Cerro del Molle sections, in San Juan Province. These authors interpreted their materials as closely resembling R. bronni (Barrande, 1846), although they neither assigned repository numbers nor provided photographic illustrations, but only presented basic drawings of two cephala.
Most recently, Coughlin (2000) mentioned the presence of Reedops in a nearby fossiliferous locality in the Las Minitas Range, albeit without providing an exhaustive discussion. In this respect, we find that the specimen illustrated there could belong to $R$. bronni. This interpretation would be in agreement with the observations of Baldis and Peralta (1991); unfortunately, we are unable to confirm the presence of Reedops in the Talacasto Formation based on their illustrations.

The genus Reedops has been considered problematic from a systematic point of view (McKellar and Chatterton, 2009) because its diagnostic characters -mainly the weakness of the vincular furrow - have been demonstrated to be rather variable (Campbell, 1977). Successive attempts at rediagnosis have pointed out further postcephalic characters such as: very narrow (tr.) and long (sag., exsag.) thorax, weakly impressed to effaced pygidial segmentation, pleural furrows becoming faded backward (Chlupáč, 1977) and flattened tips of the last thoracic segments (Campbell, 1977).

The specimen studied herein does not display any of these features. Instead, its particularly wide (tr.) and nearly subrounded thorax, and pygidium with strongly defined segmentation are typical of Paciphacops, fide Maksimova (1972). This would suggest the presence of a second Paciphacops species in the same locality.

Nevertheless, given that some taxa closely related to Paciphacops — such as Kainops - are distinguished on the basis of their cephalic features (thoracic characters having received only secondary attention), a reliable generic assignment is not possible; consequently the material is tentatively referred to Paciphacops.

Superfamily Acastoidea Delo, 1935

Family Calmoniddae Delo, 1935

Genus Talacastops Edgecombe, Vaccari and Waisfeld, 1994

Type species. Talacastops zarelae Edgecombe, Vaccari and Waisfeld,1994 from the Lochkovian of the Talacasto Formation, at the Quebrada de las Aguaditas section, San Juan Province, Argentina; original designation.

Talacastops zarelae Edgecombe, Vaccari and Waisfeld, 1994

Figure 3.1-9

Material. One pygidium (PULR-111 A-B) and six fragmentary cephala (PULR-112-PULR-117).

Description. A complete description of this species was provided by Edgecombe et al. (1994a) in the original work; 
herein we improve the characterization of the anterior cephalic doublure and the pygidium, on the basis of a new and better preserved material.

Anterior cephalic doublure (Fig. 3.6) with a curved row of large spines frontally (Fig. 3.1-3) located immediately behind and subparallel with respect to anterior margin. Spines directed downward and slightly forward, and of two types, i.e., subconical, acutely ended and relatively short; or longer, subcylindrical, with thin basal coarser distal portions, distal portion ending in blunt tip (Fig. 3.1-3). Both kinds of spines appear to alternate but not in a regular pattern (Fig. 3.3). Doublure (Fig. 3.6) relatively long (sag., exsag.) continuing backward in smooth and approximately flat platform, with an evenly curved posterior margin (exsag.). Hypostome not observed. Only available pygidium (Fig. 3.7-9) broken anteriorly and articulating half ring not observed. Pygidium 11 $\mathrm{mm}$ long (sag.) and $20 \mathrm{~mm}$ wide (tr.), although somewhat distorted. Pygidium broadly subtriangular in dorsal view, high and convex in posterior view, and convex and abruptly inclined backward in lateral view. Dorsal surface of exoskeleton fine and evenly granulated, lacking spines, with tubercles not clearly defined but just insinuated exsagittally on axial rings or pleural ribs. Broad axis (tr.), clearly segmented with at least 5-6 long (sag., exsag.) distinguishable axial rings, becoming rapidly effaced backward. Axial furrows moderately shallow with subrounded and moderately deep apodemal pits at junction with pleural furrows. Pleural field clearly segmented, with more than six distinguishable ribs that are strongly bent backward. Pleural furrows long (exsag.) and moderately deep, markedly bent backward as pleural ribs. No conspicuous pygidial border observed. Pygidial margin apparently smooth in general; yet, anteriormost pygidial pleurae showing blunt spine-like and inflated tips slightly projecting backward.

Discussion. According to the diagnosis, specific assignment of the studied specimens to T. zarelae is based on the semicircular anterior margin of the frontal glabellar lobe; axial furrow apparently shallow against L3; glabellar and fixigenal spines very long; paired spines absent on medial region of L3; and S2 shallow, non-apodemal, directed anterolaterally, with its proximal end flexed backward. Furthermore, the single recovered pygidium (Fig. 3.7-9) is strictly similar to that illustrated by Edgecombe et al. (1994a, p. 455, fig. 5b-c). This pygidium is only the second one known for the species to present. The record from Las Minitas is the second occurrence of this taxon, as T. zarelae had been previously recorded only from Lochkovian levels in the lower part of the Talacasto Formation at the Las Aguaditas Creek section, where it is relatively frequent, as in the Las Minitas assemblage. The implications of the strong similarity between the two trilobitebearing levels are dealt with in the general discussion section.

\section{Genus Tormesiscus Waisfeld, Edgecombe and Vaccari, 1994}

Type species. Tormesiscus hildae Waisfeld, Edgecombe and Vaccari, 1994 from the Lochkovian of the Talacasto Formation at the Quebrada deTalacasto Section, San Juan Province, Argentina; original designation.

\section{Tormesiscus cf. hildae Waisfeld, Edgecombe and Vaccari, 1994}

Figure 3.14

Material. PULR-130, a partially complete articulated specimen. Discussion. The tentative specific recognition is based on the presence of S1 with a moderately wide (tr.) apodemal impression, shallowing distally adjacent to the axial furrow; and S2 apparently very shallow. Other characters, such as frontal lobe inflation or impression degree of S3, could not be adequately observed, due to poor preservation; thus the material is left in open nomenclature. However, in accordance with the diagnosis, the apomorphies recognized would allow distinction of this species from its Emsian sister taxon T. gloriae Waisfeld, Edgecombe and Vaccari, 1994, as discussed by Waisfeld et al. (1994). T. hildae is considered Lochkovian in age, as it has been repeatedly recorded in a low stratigraphic position within the lower part of the Talacasto Formation in the Central Precordillera of San Juan Province at Las Aguaditas Creek, Talacasto Creek, Tambolar section, Las Tunas Creek and the Cerro del Fuerte section (personal observation). These data are consistent with previous interpretations on the stratigraphic position and age of the Las Minitas outcrops (Vaccari, et al., 2008). The new data discussed herein indicate that Tormesiscus is a frequent and widely distributed element along the basin, showing a consistent stratigraphic occurrence and therefore possibly proving useful as a biostratigraphic indicator.

\section{Superfamily Dalmanitoidea Vogdes, 1890 \\ Family Dalmanitidae Vogdes, 1890 \\ Subfamily Dalmanitnae Vogdes, 1890 \\ Gen et sp. indet \\ Figure 3.13}

Material. PULR 132 A-B, a fragmentary pygidium, preserved as an external mold. 
Description. Maximum preserved length of pygidium (sag.) $21 \mathrm{~mm}$; width $18 \mathrm{~mm}$ (tr.). Axial region moderately convex, with conspicuous segmentation. Axial furrows narrow (tr.), moderately shallow and straight, gradually converging posteriorly. Axis with 12 well-defined rings preserved (excluding articulating half-ring). Axial rings moderately long (sag., exsag.), bearing a posterior dorsal spine that becomes progressively smaller towards posteriormost rings. Interannular rings only insinuated on posterior part of anteriormost axial rings, rendering the axial ringW-shaped. Dorsal pleural field moderately convex adaxially, becoming steeply inclined laterally beyond fulcrum. Ten or eleven pleural ribs preserved, clearly distinguishable (excluding the first half pleural rib). Anteriormost pleural ribs (particularly the first four) somewhat sinuous (slightly convex backward near axial furrow, then strongly forwardly convex at fulcrum) bending abaxially backward at fulcrum. Posteriormost pleural ribs becoming progressively nearly straight and backwardly oriented, trending to be parallel to axis. Interpleural furrows effaced next to axial furrow, starting at midpoint (tr.) of pleural rib as a faint line, and then becoming a conspicuous fine line at fulcrum toward pygidial margin. Pleural furrows long (exsag.) and moderately deep, deepest and narrowest (exsag.) next to axial furrow, broadening (exsag.) distally, shallowing at fulcrum toward the pygidial margin, becoming progressively narrower (exsag.) and shallower backward. Pygidial border and margin not adequately observed because of fragmentary nature of available material.

Discussion. Considerations at the subfamily level follow discussions on Dalmanitinae and Synphoriinae by Campbell (1977), Holloway (1981), and Holloway and Pires de Carvalho (2009). The single available specimen is tentatively referred to the Dalmanitinae considering the relatively long (exsag.) and rather lanceolated pygidial pleural furrows, which are moderately deep and asymmetrical; they define anterior and posterior pleural bands of different strength, the latter slightly decreasing in height toward the border, which cannot be adequately observed.

The studied pygidium, although without its posterior end preserved, resembles the partially coeval dalmanitine Gamonedaspis scutata Braniša and Vaněk, 1973, from the Lower Devonian of Bolivia figured by Edgecombe (1993). Similarities lie in the general anterolateral shape of the pleural field, form of the ribs and degree of their progressive backward redirectioning, together with the dorsal convexity. Differences lie in the broader (exsag.) and deeper pleural and interpleural furrows in G. scutata, which has a double row of coarse faint tubercles exsagittally along the axis.
Similarly, the specimen under consideration can be differentiated from the dalmanitine Kazachstania Maksimova, 1972, known from the uppermost Silurian or probably lowermost Devonian from the Catavi Formation in Bolivia (Edgecombe and Ramsköld, 1994), and the Silurian from the Los Espejos Formation at Cerro del Fuerte, Argentina (Waisfeld et al., 1988; Edgecombe and Ramsköld, 1994). Differences include better impressed interpleural furrows, longer (exsag.) pleural furrows, and straighter pleural ribs in Kazachstania. In Argentina, the only similarly dated (Early Devonian) dalmanitid is the synphorine Dalmanitoides drevermanni Thomas, 1905, described from Pragian levels of the Talacasto Formation at the Loma de los Piojos section, near Jáchal, San Juan Province (Cerro del Agua Negra section of Thomas, 1905). Recent illustrations of the type material, which is housed in Germany (Holloway and Pires de Carvalho, 2009), prevent referral of the specimen from Las Minitas to that taxon, based on the absence of tubercles and obvious differences in pygidial shape and morphology of the pleural ribs and furrows, features of subfamilial significance.

Reliable comparisons to Dalmanites sudamericanus Benedetto and Martel in Baldis et al., 1976 from the Silurian of the Lipeón Formation, Jujuy Province, Argentina, cannot be made without more and better material.

Order Proetida Fortey and Owens, 1975

Superfamily Proetoidea Hawle and Corda, 1847

Family Proetidae Salter, 1864

Subfamily Proetinae Salter, 1864

Genus Unguliproetus Erben, 1951

Type species. Proetus unguloides Barrande, 1846, from the uppermost Emsian (Dalejan) of the Suchomasty Limestone, Bohemia; original designation.

\section{Unguliproetus? sp.}

Figure 3.10-12,15

Material. PULR-128 A-B and PULR-129 A-B, a fragmentary cranidium and an associated fragmentary pygidium, preserved in the same nodule.

Description. Cranidium (Fig. 3.10-12) 13 mm long (sag.) and measuring almost the same between more divergent points (laterally) of anterior branches of facial suture; cranidium sagittally elongated, with very subdued sculpture to smooth dorsally; anterior margin even and moderatelly arched in dorsal view; anterior area shortest medially (sag.), gently inclined forward and slightly concave in lateral view; 
anterior border, anterior border furrow and preglabellar field not clearly delimited on the anterior area; preglabellar furrow exceedingly narrow (sag., exsag.) and shallow, becoming a line parallel to the anterior glabellar contour; glabella sub-conical to ogival (slightly tongue-shaped) in dorsal view, with maximum width at L1 about 0.8 of length (sag., including occipital ring), weakly inflated to nearly flattened in lateral view, with even, slight dorsal convexity sagittally and transversely; axial furrows moderately convex, most rapidly convergent forward from anterior side of L1, exhibiting a moderate anterolateral constriction associated with small shallow apodemal fossula anteriorly; LO (occipital ring) long (sag., exsag.) yet slightly shorter than anterior area, elongated laterally at junction with axial furrow, as high as posterior part of median glabellar lobe in lateral view, nearly flat at top; L1 large, but weakly defined; L2 faint; SO short (sag., exsag.) and shallow, longer and shallower behind L1; S1 faint, widespread, nearly anterolaterally directed; S2 effaced; eye ridge weak, insinuated next to anterior point of lateral constriction at apodemal fossula; interocular fixigena incompletely known.

Pygidium (Fig. 3.15) sub-triangular, $12 \mathrm{~mm}$ long (sag.), about 0.7 of inferred pygidial width anteriorly. Axial region moderately convex, with weakly defined segmentation. Axial furrows moderately broad (tr.), moderately deep, shallowing posteriorly, and approximately straight. Axis with 8-9 defined rings, abruptly ended posteriorly. Pleural field gently convex in posterior view. Five anteriormost pleural ribs most distinguishable, broadly (exsag.) separated, slightly convex forward and defined by delicate pleural furrows; posteriormost pleural ribs otherwise more delicately marked and much more narrowly (exsag.) spaced. Interpleural furrows completely effaced, particularly between anteriormost pleural ribs. Pleural ribs and furrows becoming progressively fainter posteriorly and next to axial furrows. Because of breakage, the lateral pygidial border displays the doublure anteriorly, which carries delicate subparallel terrace lines; continuation of more narrowly spaced pleural ribs can be observed posteriorly, where dorsal surface is preserved. Pygidial margin entirely smooth.

Discussion. The pygidium and cranidium described are closely associated in the same concretion, and therefore they are considered as belonging to the same individual. Some tectonic distortion is present and the fragmentary and weathered preservation is not good enough to show delicate ornamentation, particularly in the cranidium. Nevertheless, an ogival or subconical glabellar outline is noticeable. This feature was particularly outlined as diagnostic of the genus Unguliproetus, following rediagnoses by successive authors
(Harrington et al., 1959; Alberti, 1969; Šnajdr, 1980) after the brief original diagnosis given by Erben (1951). Other generic glabellar features observable in the specimen such as a depressed profile, absence of strongly impressed lateral lobes, and a very gentle dorsal curvature, were discussed by Šnajdr (1980) to give a restricted diagnosis of Unguliproetus, and differentiate it from Pragoproetus Šnajdr, 1977. However, the only slightly inclined frontal area, the weakly defined anterior border, faded anterior border furrow, and apparently long and moderately segmented pygidium are not typical of Unguliproetus, suggesting a possibly different taxon in the Las Minitas outcrops. According to this, and because available material is scarce and poorly preserved, the specimens are left in open nomenclature.

This is the first record of a proetid trilobite in the Devonian of Argentina. Additional unpublished material currently under study referable to similar Lower Devonian proetids collected from the lower part of the Talacasto Formation there is mentioned herein only in order to emphasize the taxonomic similarity of trilobites in this stratigraphic position along the basin, and in order to support correlations.

\section{GENERAL DISCUSSIONS ON AGE AND STRATI- GRAPHIC IMPLICATIONS}

The trilobite assemblage described herein is the same as that accompanying Talacastops zarelae in the lower section of the Talacasto Formation at the Las Aguaditas Creek in San Juan Province, as described by Edgecombe et al. (1994a). Shared taxa include Talacastops zarelae, P. (Paciphacops) sp. and Tormesiscus cf. hildae. Notably, T. zarelae and P. (Paciphacops) sp. are known exclusively from these two localities. Furthermore, in both cases a distinctive feature is the dominance of $P$. (Paciphacops) sp., in terms of abundance, which is identically represented by similar articulated moult ensembles, whereas other trilobite taxa are mostly disarticulated and less abundant. A reliable correlation can be made between both localities based on the very same taxonomic composition of trilobites. Consequently, since the fossil levels at Las Aguaditas are considered Lochkovian (Herrera, 1991, 1993; Edgecombe et al., 1994a), the same age is suggested for the trilobites from Sierra de Las Minitas. Nevertheless, based on the presence of the genus Reedops reported by Coughlin (2000), strata of probable Pragian age could be exposed in the area.

Baldis (1975b) pointed out the relevance of trilobites - specifically from the Talacasto Formation - for perform- 
ing biostratigraphic correlations in the Lower Devonian from the Argentine Precordillera. However, biostratigraphic frameworks proposed for this unit have been based solely on its rich brachiopod fauna (Herrera, 1993; Racheboeuf and Herrera, 1994; Herrera and Bustos, 2001). This allowed correlations of this unit with those in other basins across the Malvinokaffric Realm, fundamentally in Bolivia (Racheboeuf et al., 1998). However, the very same faunal elements of the Talacasto Formation had never been recognized outside the Central Precordillera in Argentina. Recognition of the assemblage described herein allows — for the first timea rigorous correlation based on Lower Devonian trilobites from the Talacasto Formation.

On the other hand, within the lower section of the Talacasto Formation, stratigraphic intervals bearing fossil-rich nodules at the Las Aguaditas section correspond to Facies Sequence A of Astini (1991). Although fossiliferous rock successions at Sierra de Las Minitas differ from them in that they show a slightly more greenish weathered surface and are affected by penetrative cleavage, they do resemble rocks from the Talacasto Formation when analyzed in detail. Therefore, considering facies and taphonomic similarities, the interval yielding trilobites also corresponds to the same unit on a lithological basis. Thus, we suggest that the Quebrada del Escarabajo Formation of Coughlin (2000) is at least in part equivalent to the Talacasto Formation, and consequently we propose to expand the use of Talacasto Formation for exposures in this area of Sierra de Las Minitas, replacing thus the informal name Quebrada del Escarabajo Formation. This redefinition stretches the extent of the Talacasto Formation into the northern Precordillera, demonstrating that this region was part of the Precordilleran Early Devonian basin and thereby suggesting a much larger extent toward the north than that previously inferred for the Lower Devonian foreland basin stratigraphy (Bustos and Astini, 1997).

The remarkable lateral continuity and regularity observed — on both lithologic and taphonomic grounds- between the outcrops of the Talacasto Formation in the Precordillera of San Juan and those from the Sierra de Las Minitas elicit additional considerations regarding environmental aspects. The same facies association, identical faunal content and strong preservational features (shape, size and color of the fossil-rich nodules) in the fossiliferous intervals are striking. Everything indicates shared depositional environment and burial histories allowing preservational identity for the nodule-bearing levels that can be reliably correlated along almost $200 \mathrm{~km}$ (Vaccari et al., 2008) in San Juan and La Rioja provinces. Consequently, uniform depositional conditions can be inferred along the Precordillera sedimentary basin during Lochkovian times. This is consistent with previous interpretations suggesting a muddy shelf depositional system for the Talacasto Formation, based on stratigraphic and sedimentological data (Astini, 1991, Bustos and Astini, 1997).

It is also worth mentioning that this interpretation does not disagree with previous work in the region. The geology of Sierra de Las Minitas is complicated by several folding and faulting stages (Coughlin, 2000, fig. 1), and while our suggestion is that the older unit in the area is the Talacasto Formation, this does not necessarily indicate that everything below the unconformity at Agua de Carlos, overlain by the Río del Peńón Formation (Lower Pennsylvanian), corresponds to the Talacasto Formation (Fig. 1). Carrizo (1998), Carrizo and Azcuy (1998) and Azcuy et al. (1999) also pointed that at Sierra de Las Minitas two other units, i.e., the Agua de Lucho and the Cerro Tres Cóndores formations, also underlie the Agua de Carlos unconformity, leaving open the question regarding their precise stratigraphic age. Our new interpretation allows stratigraphic bracketing of the age of these two units, originally defined by González and Bossi (1986) immediately to the north. These authors assigned a Mississippian age to these two units, an age that appears to be consistent with our new interpretation of the stratigraphy at the Sierra de Las Minitas.

\section{ACKNOWLEDGMENTS}

A. Sterren and M. Albertengo kindly collaborated in the field works of the authors. Lodging during field days was provided by the building company Benito Roggio S.A. This study was possible thanks to financial support by CONICET and ANPCyT (Agencia Nacional de Promoción Científica y Tecnológica) PICT-2005-33630 granted to Ricardo Astini, and 200601272 granted to Claudia Rubinstein.

\section{REFERENCES}

Aceñolaza, F. 1971. Geología estratigráfica de la zona comprendida entre Punta de Agua y Rincón Blanco, Dpto. Gral. Lamadrid, La Rioja. Acta Geológica Lilloana 11: 125-150.

Aceñolaza, F.G., Benedetto, J.L. and Salfity, J. 1972a. El Neopaleozoico de la Puna argentina, su fauna y su relación con áreas vecinas. Anales de la Academia Brasilera de Ciencias 44: 5-20.

Aceñolaza, F., Koukharsky, M., Salfity, J.S. and Viera, O. 1972b. Presencia de sedimentitas devónicas y neopaleozoicas en la Puna de Atacama, Provincia de Salta, Argentina. Revista de la Asociación Geológica Argentina 27: 346-354.

Alberti, G.K.B. 1969. Trilobiten des jüngeren Siluriums sowie des unterund Mitteldevons. I. Abhandlungen der Senckenbergischen Naturforschenden Gesellschaft 520: 521-692.

Amenábar, C.R. 2009. Middle Devonian microfloras from the Chigua Formation, Precordillera region, northwestern Argentina. Geological Society of London, Special Publications 314: 177-192. 
Antonelli, J. and Ottone, E.G. 2006. Palinología de coronas del Devónico y Carbonífero Superior del Pozo YPF.SE.EC.X-1, El Caburé, provincia de Santiago de Estero, Argentina. Revista del Museo Argentino de Ciencias Naturales, Nueva Serie 8: 111-117.

Astini, A.R. 1991. Sedimentología de la Formación Talacasto: plataforma fangosa del Devónico precordillerano, provincia de San Juan. Revista de la Asociación Geológica Argentina 44: 277-294.

Astini, A.R. 1996. Las fases diastróficas del Paleozoico Medio de la Precordillera del Oeste argentino - Evidencias estratigráficas $13^{\text {er Congreso Geo- }}$

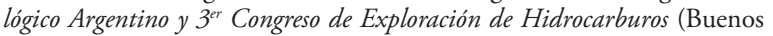
Aires), Actas 5: 509-526.

Astini, A.R. and Ezpeleta, M. 2008. Evidencias de la glaciación devónica en el ámbito andino, Sierra de las Minitas, La Rioja, Argentina. $17^{\circ}$ Congreso Geológico Argentino (Jujuy), Actas 3: 1061-1062.

Azcuy, C.L. and Carrizo, H. A. 1995. Archaeosigillaria conferta en el Bolsón de Jagüé, Provincia de La Rioja, Argentina. Ameghiniana 32: 279-286.

Azcuy, C.L., Carrizo, H.A. and Caminos, R. 1999. Carbonífero y Pérmico de las Sierras Pampeanas, Famatina, Precordillera, Cordillera Frontal y Bloque de San Rafael. In: R. Caminos (Ed.), Geología Argentina, Anales del Servicio Geológico Minero Argentino 29: 261-318.

Baldis, B.A. 1967. Some Devonian trilobites of the Argentine Precordillera, International Symposium of Devonian System (Calgary), Proceedings, p. 789-796.

Baldis, B.A. 1972. Trilobites Devónicos de la Sierra de Santa Bárbara (Provincia de Jujuy). Ameghiniana 9: 35-44.

Baldis, B.A. 1975a. El Devónico Inferior en la Precordillera Central. Parte I: Estratigrafía. Revista de la Asociación Geológica Argentina 30: 53-83.

Baldis, B.A. 1975b. Valoración de elementos faunísticos para una zonación y datación de edades en el Devónico Inferior de la Precordillera Argentina. $1^{e r}$ Congreso Argentino de Paleontología y Bioestratigrafía (Tucumán), Actas 1: 219-240.

Baldis, B.A. 1979. Paleozoogeografía de los trilobites devónicos en Sudamérica austral. Ameghiniana 16: 209-216.

Baldis, B.A. and González, S.B. 1981a. Conocimiento actual de la distribución de los trilobites acástidos de Sudamérica. $2^{\circ}$ Congreso LatinoAmericano de Paleontología (Porto Alegre), Anais: 59-69.

Baldis, B.A. and González, S.B. 1981b. Primeros trilobites devónicos del subsuelo de la llanura Chaco-Paranaense. Comunicaciones del Museo Argentino de Ciencias Naturales "Bernardino Rivadavia" e Instituto Nacional de Investigación de las Ciencias Naturales 1: 45-57.

Baldis, B.A. and Longobucco, M. 1977a. Trilobites devónicos de la precordillera noroccidental (Argentina). Ameghiniana 14: 145-161.

Baldis, B.A. and Longobucco, M. 1977b. Un trilobite del Devónico inferior de la Puna. Ameghiniana 14: 170-174.

Baldis, B.A. and Peralta, S.H. 1991. El género Reedops Richter and Richter (Trilobita) en el Silúrico-Devónico de la Precordillera de San Juan. Revista Técnica de Yacimientos Petroliferos Fiscales Bolivianos 12: 129-131.

Baldis, B.A. and Sarudiansky, R. 1975. El Devónico del Noroeste de la Precordillera Argentina. Revista de la Asociación Geológica Argentina 30: 301-329.

Baldis, B.A., Levy, R., and Nullo, F. 1973. Acerca de una fauna marina devónica de la Puna salteńa. $5^{\circ}$ Congreso Geológico Argentino (Villa Carlos Paz), Actas 3: 413-421.

Baldis, B.A., Benedetto, L., Blasco, G. and Martell, M. 1976. Trilobites siluro-devónicos de la Sierra de Zapla (Noroeste de Argentina). Ameghiniana 13: $185-225$.

Barrande, J. 1846. Notice préliminaire sur le systême Silurien et les Trilobites de Bohême. Hirschfeld, Leipzig, 97 p.

Benedetto, J.L. and Sánchez, T. 1990. Fauna y edad del estratotipo de la
Formación Salar del Rincón (Eopaleozoico, Puna argentina). Ameghiniana 27: 317-326.

Benedetto, J.L., Racheboeuf, P.R., Herrera, Z., Brussa, E.D. and Toro, B.A. 1992a. Brachiopodes et biostratigraphie de la Formation de Los Espejos, Siluro-Dévonien de la Précordillère (NW Argentine). Geobios 25: 599-637.

Benedetto, J.L., Sánchez, T. and Brussa, E.D. 1992b. Las cuencas silúricas de América Latina. In: J.C. Gutiérrez Marcos, J. Saavedra, and I. Rábano (Eds.), Paleozoico inferior de Iberoámerica, Publicación de la Universidad de Extremadura, Badajoz, p. 119-148.

Bengtson, P. 1988. Open nomenclature. Palaeontology 31: 223-227.

Braniša, A.L. and Vaněk, J. 1973. Several new trilobite genera of the superfamily Dalmanitacea Vogdes, 1890 in the Devonian of Bolivia. Véstník Ustredního Ústavu Geologického 48: 97-101.

Bustos, U.D. and Astini, A.R. 1997. Formación Punta Negra: análisis secuencial y evolución de la Cuenca Devónica Precordillerana. Revista de la Asociación Argentina de Sedimentología 4: 97-111.

Caminos, R., Fauqué, L., Cingolani, C., Varela, R. and Morel, E. 1993. Estratigrafía y estructura del Devónico-Carbonífero en el sector septentrional de la sierra de la Punilla, Precordillera de la Rioja y San Juan. $12^{\circ}$ Congreso Geológico Argentino y $2^{\circ}$ Congreso de Exploración de Hidrocarburos (Mendoza), Actas 2: 31-41.

Campbell, K.S.W. 1977. Trilobites of the Haragan, Bois d'Arc and Frisco Formations (Early Devonian) Arbuckle Mountains Region, Oklahoma. Oklahoma Geological Survey Bulletin 123: 1-227.

Carrizo, H.A. 1998. [Estudio de floras eocarboniferas de Argentina y su comparación con las de otras regiones relacionadas. PhD. dissertation, Facultad de Ciencias Naturales, Universidad Nacional de Salta, Salta, 304 p. Unpublished]

Carrizo, H.A. and Azcuy, C.L. 1995. La zona NBG en las inmediaciones del río Agua de Carlos, Provincia de La Rioja, Argentina. Ameghiniana 32: $271-278$.

Carrizo, H.A. and Azcuy, C.L. 1998. El perfil del cerro Mudadero y su flora fósil. Provincia de La Rioja, Argentina. Acta Geológica Lilloana 18: 81-99.

Castellaro, H. 1966. Guía Paleontológica Argentina. Parte 1: Paleozoico, Sección III: faunas silúricas y devónicas. Publicaciones Especiales CONICET, Buenos Aires, 164 p.

Chlupáć, I. 1977. The phacopid trilobites of the Silurian and Devonian of Czechoslovakia. Rozpravy Ústredního Ústavu Geologického 43: 1-172.

Coughlin, T.J. 2000. [Linked orogen-oblique fault zones in the central Argentine Andes: the basis for a new model for Andean orogenesis and metallogenesis. PhD dissertation, Queensland University, Queensland, Australia, 207 p. Unpublished.]

Cuerda, A.J. and Baldis, B.A. 1971. Silúrico-Devónico de la Argentina. Ameghiniana 8: 128-164.

Delo, D.M. 1935. A revision of the phacopid trilobites. Journal of Paleonto$\log$ 9: 402-420.

Edgecombe, G.D. 1993. A revision of the Devonian dalmanitid trilobite Gamonedaspis. In: R. Suárez-Soruco (Ed.), Fósiles y facies de Bolivia. Vol. 2. Invertebrados y paleobotánica. Revista Técnica de Yacimientos Petroliferos Fiscales Bolivianos 13-14: 161-166.

Edgecombe, G.D. 1994. Calmoniid trilobites from the Devonian Fox Bay Formation, Falkland Islands: Systematics and biogeography. New York State Museum Bulletin 481: 55-68.

Edgecombe, G.D. and Ramsköld, L. 1994. Earliest Devonian phacopide trilobites from central Bolivia. Palaöntologische Zeitschrift 68: 397-410.

Edgecombe, G.D., Vaccari, N.E. and Waisfeld, B.G. 1994a. Lower Devonian calmoniid trilobites from the Argentine Precordillera: new taxa of 
the Bouleia Group, and remarks on the tempo of calmoniid radiation. Geological Magazine 131: 449-464.

Edgecombe, G.D., Waisfeld, B.G. and Vaccari, N.E. 1994b. Andinacaste (Trilobita) from the earliest Devonian of Argentina. Journal of Paleonto$\log$ 68: 837-841.

Erben, H.K. 1951. Beitrag zur Gleiderung der Gattung Proetus Stein, 1831 (Trilobitae). Neues Jahrbuch für Geologie und Palaeontologie Abhandlungen 94: 5-48.

Ezpeleta, M. and Astini, R.A. 2009. The Late Devonian glaciation in western Argentina: expanding the frontiers of Gondwanan glacial epoch. International Lateinamerika-Kolloquium (Göttingen), Abstracts and Program: $95-96$.

Fauqué, L.E. and Limarino, C.O. 1991. El Carbonífero de Agua de Carlos (Precordillera de La Rioja), su importancia tectónica y paleoambiental. Revista de la Asociación Geológica Argentina 46: 103-114.

Furque, G. and Baldis, B.A. 1973. Nuevos enfoques estratigráficos en el Paleozoico del Noroeste de la Precordillera. $5^{\circ}$ Congreso Geológico Argentino (Villa Carlos Paz), Actas: 241-252.

González, C.R. and Bossi, G.E. 1986. Los depósitos carbónicos al oeste de Jagüel, La Rioja. $4^{\circ}$ Congreso Argentino de Paleontología y Bioestratigrafía (Mendoza), Actas 1: 231-236.

Grahn, Y. and Gutiérrez, P.R. 2001. Silurian and Middle Devonian Chitinozoa from the Zapla and Santa Bárbara Ranges, Tarija Basin, northwestern Argentina. Ameghiniana 38: 35-50.

Hall, J. 1861. Descriptions of New Species of Fossils from the Upper Helderberg, Hamilton, and Chemung Groups. New York State Cabinet Natural History Annual Report 14: 99-109.

Harrington, H.J. 1967. Devonian of South America. International Symposium on the Devonian System (Calgary), Proceedings 1: 651-671.

Harrington, H.J., Henningsmoen, G., Howel, B.F., Jaanusson, V., Lochman-Balk, C., Moore, R.C., Poulsen, C., Rasetti, F., Richter, E., Richter, R., Schmidt, H., Sdzuy, K., Struve, W., Størmer, L., Stubblefield, C.J., Tripp, R., Weller, J.M. and Whittington, H.B. 1959. Systematic descriptions. In: R.C. Moore (Ed.), Treatise on invertebrate paleontology. Part O. Arthropoda 1, Geological Society of America and University of Kansas, Boulder and Lawrence, 560 p.

Hawle, I.A. and Corda, A.J.C. 1847. Prodrom einer Monographie der böehmischen Trilobiten. Abhandlungen Kongligischen Böhemischen Gesellschaft der Wiossenschaften 5: 1-176.

Herrera, Z.A. 1991.[Taxonomía, Bioestratigrafía y Paleobiogeografía de los braquiópodos de la Formación Talacasto (Devónico) de Precordillera Argentina. PhD dissertation, Universidad Nacional de Córdoba, Córdoba, Argentina, 283 p. Unpublished.]

Herrera, Z.A. 1993. Nuevas precisiones sobre la edad de la Formación Talacasto (Precordillera Argentina) en base a su fauna de braquiópodos. $12^{\circ}$ Congreso Geológico Argentino y $2^{\circ}$ Congreso de Exploración de Hidrocarburos (Buenos Aires), Actas 2: 289-295.

Herrera, Z.A. and Bustos, U.D. 2001. Braquiópodos devónicos de la Formación Punta Negra, en el perfil del Río de las Chacritas, Precordillera Argentina. Ameghiniana 38: 367-374

Holloway, D.J. 1981. Silurian dalmanitacean trilobites from North America and the origins of the Dalmanitinae and Synphoriinae. Palaeontology 24: 695-731

Holloway, D. and Pires De Carvalho, M.G. 2009. The extraordinary trilobite Fenestraspis (Dalmanitidae, Synphoriinae) from the Lower Devonian of Bolivia. Palaeontology 52: 933-949.

Isaacson, P.E., Antelo, B. and Boucot, A. 1976. Implications of a Llandovery (Early Silurian) brachiopod fauna from Salta Province, Argentina. Journal of Paleontology 50: 1103-1112.

Iwasaki, Y. 2006. Devonian Panthalassa and phacopid trilobites. Geological Society of America, Abstracts with Programs 38: 552.
Keidel, J. 1916. La geología de las sierras de la Provincia de Buenos Aires y sus relaciones con las montañas del Cabo y los Andes. Anales del Ministerio de Agricultura, Sección Geologia, Mineralogía y Minería 11: 1-78.

Keidel, J. 1921. Observaciones geológicas en la Precordillera de San Juan y Mendoza. Anales del Ministerio de Agricultura, Sección Geología, Mineralogía y Minería 15: 7-102.

Limarino, C., Tripaldi, A., Marenssi, S. and Fauque, L. 2006. Tectonic, sea-level, and climatic controls on Late Paleozoic sedimentation in the western basins of Argentina. Journal of South American Earth Sciences 22: $205-226$

Maksimova, Z.A. 1972. Novye devonskiye trilobity Phacopoidea. Paleontologicheskii Zhurnal 1: 88-94.

McKellar, R.C. and Chatterton, B.D.E. 2009. Early and Middle Devonian Phacopidae (Trilobita) of southern Morocco. Palaeontographica Canadiana 28: 1-114.

Mingramm, A. and Russo, A. 1972. Sierras Subandinas y Chaco Salteño, In: A.F. Leanza (Ed.), Geología Regional Argentina. Academia Nacional de Ciencias, Córdoba, p. 185-235.

Padula, E., Rolleri, E., Mingramm, A.R., Criado Roqué, P., Flores, M.A. and Baldis, B.A. 1967. Devonian of Argentina. International Symposium on the Devonian System (Calgary), Proceedings 2: 165-199.

Pires De Carvalho, M.D.G. 2006. Devonian trilobites from the Falkand Islands. Palaeontology 49: 21-34.

Racheboeuf, P. and Herrera, Z.A.. 1994. On some new malvinokaffric Silurian and Devonian chonetacean brachiopods and reclassification of others. Neues Jahrbuch für Geologie und Paläontologie 9: 541-560.

Racheboeuf, P.R., Dalenz Farjat, A. and Lefebvre, B. 1998. The Devonian Gamoneda section of southern Bolivia: new biostratigraphical and palaeobiogeographical data. Revista Española de Paleontología 13: 175-186.

Ramsköld, L. and Werdelin, L. 1991. The phylogeny and evolution of some phacopid trilobites. Cladistics 7: 29-74.

Richter, R. and Richter, E. 1925. Unterlagen zum Fossilium Catalogus. Trilobita II. Senckenbergiana 7: 126.

Richter, R. and Richter, E. 1942. Die Trilobiten der Weismes - Shichten am Hohen Venn, mit Bemerkungen über die Malvinocaffrische Provinz. Senckenbergiana 25: 156-279.

Rickards, R.B., Ortega, G., Basset, M., Boso, M.A. and Monaldi, C.R. 2002. Talacastograptus, an unusual biserial graptolite, and other Silurian forms from Argentina and Bolivia. Ameghiniana 39: 343-350.

Rubinstein, C.V. and Vaccari, N.E. 2004. Cryptospore assemblages from the Ordovician/Silurian boundary in the Puna, North-West Argentina. Palaeontology 47: 1037-1061.

Rustán, J.J. 2008. Lower Devonian aulacopleurid trilobites from Argentina. In: I. Rábano, R. Gozalo and D. García-Bellido (Eds.), Advances in trilobite research, Cuadernos del Museo Geominero de España 9: 345-349.

Salter, J.W. 1864. A monograph of the British trilobites from the Cambrian, Silurian, and Devonian formations. Part 1. Monographs of the Palaeontographical Society 16: 1-80.

Šnajdr, M. 1977 New genera of Proetidae (Trilobita) from the Barrandian, Bohemia. Vesstník Ustréedního Ústavu Geologického 52: 293-297.

Šnajdr, M. 1980. Bohemian Silurian and Devonian Proetidae (Trilobita). Rozpravy Ústréedního Ústavu Geologického 45: 1-324.

Stappenbeck, R. 1910. La precordillera de San Juan y Mendoza. Anales del Ministerio de Agricultura, Sección Geologia, Mineralogía y Minería 4:1-187.

Thomas, I. 1905. Neue Beiträge zur Kentniss der Devonischen Faunen Argentiniens. Zeitschrift der Deutschen geologischen Gesellschaft 57: 233290. 
Vaccari, N.E., Waisfeld, B.G. and Edgecombe, G.D. 1994. Calmoniid Trilobites of the Lower Devonian Scaphiocoelia zone in the Argentine Precordillera. Geobios 27: 591-608.

Vaccari, N.E., Rustán, J.J., Astini, R.A. and Ezpeleta, M. 2008. El Devónico fosilífero en la Sierra de las Minitas, Bolsón de Jagüé, provincia de La Rioja, Argentina. $17^{\circ}$ Congreso Geológico Argentino (Jujuy), Actas 3: 1505.

Vogdes, A.W. 1890. A bibliography of Paleozoic Crustacea from 1698 to 1889 including a list of North American species and a systematic arrangement of genera. United States Geological Survey Bulletin 63: 1-177.

Waisfeld, B.G. and Sánchez, T. 1993. Trilobites silúricos de la Formación Lipeón en el noroeste argentino (Sierra de Zapla, Prov. de Jujuy). Ameghiniana 30: 77-90.

Waisfeld, B.G., Edgecombe, G.D. and Vaccari, N.E. 1994. Tormesiscus, a new blind calmoniid trilobite from the Lower Devonian, Argentine Precordillera. Geologica et Palaeontologica 28: 27-43.
Waisfeld, B.G., Toro, B. and Brussa, E. 1988. Trilobites silúricos de la Formación Los Espejos, sector occidental del cerro del Fuerte, Precordillera de San Juan, Argentina. Ameghiniana 25: 305-320.

Wright, A.J. and Haas, W. 1990. A new Early Devonian spinose phacopid trilobite from Limekilns, New South Wales: morphology, affinities, taphonomy and palaeoenvironment. Records of the Australian Museum 42: $137-147$.

doi: 10.5710/AMGH.v48i1(335)

Recibido: 27 de abril de 2010

Aceptado: 21 de diciembre del 2010 